\title{
On Coaling Ships
}

\section{Lieutenant T. Y. Greet R.N.}

To cite this article: Lieutenant T. Y. Greet R.N. (1889) On Coaling Ships, Royal United Services Institution. Journal, 33:147, 69-79, DOI: 10.1080/03071848909441229

To link to this article: http://dx.doi.org/10.1080/03071848909441229

\section{Published online: 12 Nov 2009.}

Submit your article to this journal $\pi$

Џll Article views: 5

Q View related articles $₫$ 
Wednesdag, Febraary 6, 1889.

Resr-Admiral P. H. COLOMB, Member of Council, in the Clair.

\section{ON COALING SHIPS.}

B5 Licutenant T. Y. GREet, R.N.

(Rend in his nbsence by Mr. R. A. Baillic, C.E.)

Axrnont who witnessed the Mlanouvres of 1888 must have been struck by the deplorable condition of the conling arrangements of tho Flect. 'This, the most important factor in the whole science of naval warfare, nppears to hare been lost sight of in the great, and certainly vers importint items, of speed, armour, and guns. Yet what will be the use of these, if the ship cannot more for want of the means of propulsion? Take one example-there are many-the Blockading Squadron of I Iough Swilly. It mast be remembered that the enemy was in his own port, he could constantly replenish his bunkers. But how different the case of the Blockading Squadron: thicy were alwass on the move-which meant using coal, especially as they had to he ready at short notice to go full speed - and tho consumption of theso big ships is considerable; in consequence, one or more of them was always out of action, filling up with coal, so that really a flect of ten ships can only be considered one of eight. Now, while these two ships are coaling, the remainder are stendily but surely cating away at their coal; suddenly the blockado is broken, the Blockaded Flect shoots out well filled up with coal. The Admiral of tho Blockading Fleet follows, hat how far? His ships have only half their bunkers full, or perhaps sone are nearly full and others nearly empt5, and to his disgust he has either to give up the clinse, or risk capture through going on with an inferior force; or perhaps in the excitement he forgets that coal is running short in some of the ships, and they have to be left behind to their fate, or towed by others into a port. Can anybody imagine angthiug moro heartbreaking or more calculated to lead to disaster i Yet I think this must hare been apparent to every man in the Flect. Surely the time has now come when this all-important question should be given the attention which it merits; let speed, gurs, and armour rest awlile-13ot a bad idea, as people appear to be getting somewhat mised ou those subjects through orer-attention-and they will then be able to go back to them with redoubled rigour, their minds strengthened by change and rest.

Now, let us sce some statistics on this coaling. Luckily; during 
the mancurres the weather was for the most part fine; it might be otherwise. In the first place, ships had to go some distance to a larbour; this meant coal both to get there aud also to return to the Flect, as it hind to be dono at a somerhat quick rate of stenming, coaling at sea under the present arrangenents being almost out of the question, set it could be done in rers fine weather. Private ressels are afraid to go alongside a man-of-rsar, eren in rery ordinnry weather, for fear of getting store in; of -course this is natural, but it will not do on serrice. The Admiralty ought to hare their own colliers. The following are some of the times talsen in coaling :-

$$
\left.\begin{array}{l}
\text { "Agincourt," at Plsmouth, with a large lighter on } \\
\text { cach side, fitted with derricks and steam winclies } \\
\text { and crery facilits, oning to her numerous ports }
\end{array}\right\} \text { 500 tons. } 12 \text { hours. }
$$

At Spithead, it was really pitiful to see a lighter with two small

\begin{tabular}{|c|c|c|c|c|c|c|}
\hline Tlee "Agincourt" & & & 157 & ons. & $9]$ & ours \\
\hline The "Shannon" & $"$ & & 146 & , & & $"$ \\
\hline The "Iron Duke" & ") & ......... & 106 & "1 & 91 & " \\
\hline 'The "Tartar" & " & $\ldots \ldots \ldots \ldots \ldots$ & .63 & " & 6 & \\
\hline The "Septude" & $"$ & ......... & 250 & $"$ & 10 & \\
\hline The "Intlerible" & " & & 227 & $"$ & 12 & $"$ \\
\hline The "Inconstaut" & " & $\ldots \ldots \ldots \ldots$ & 107 & $"$ & $13 !$ & " \\
\hline
\end{tabular}
derricks coaling a ship, ono bar going up at a time. The abore arc the arrangements at the tro principal Naval Arsenals in the Kingdow.

Now, from colliers at Iamlash, which mas bo tatsen as an example of what would go on. in war-time, and which had two hatehes and two steam winches-

At Slicep Haven, in a heavy swell, and coaling all uight in pouring rain from a collier-

The "Iron Duke" took in............. 116 tous. $9 \frac{2}{2}$ hours. Tho "Iron Dutc" took in, at Iocknndaile 220 "

In the Dorns from horse-boats carrying about 12 tons, which had to be hauled to and from the collier to the ship, and using cutter's for towing, bags being filled by men from ship:-

Tho "Iron Duko" took in........... 97 tons. 12 hours.

The following gives some idea of what is at present considered smart work in coaliner:-Ono Commander signals to another, "375 tons in 19 hours, what do sou think of it?" Ict considering that ships carry 1,000 tons as a rule, this woald mean a ship being out of action for nearls three dags; and one has to consider what would be the result to the men? They come away from a blockade harassed and worn ont by the anxicts of night and day look-out and constant attack by torpedo-boats, to bare three days of utter discomfort and 
extreme hayd work, which I renture to say wonld swell the sick list to an alarning extent, and so tend to cripple the fighting capabilities of tho ship, as every man is a fighting factor.

Now, from the foregoing, it is crident that what is requircd is that a ship should be able to take in her coal on her station in the blockade, and at a rery quick rate; also that she should constantly replenish, and so be ready for ans contiugency. There is a great adrantage iu filling up frequently beforo too much is used; if necessary a portion, according to dcck space, can be left on deck more conveniently and stowed at leisure, as erergbody knows it is the last part of coaling that takes so long on account of the stowage. This lcacls us to another matier which grcatly necds altcration, that is the present shape and position of the bunkers and the means of filling them. It rould appear as if when the ship is designed ererything has its place allotted, after which the remaining space, mostly boles and corners, is designated "coals :" therein lies a great causo of delay. Why not nake the bunkers of plain shape; wing bunkers round the engines and boilers, and plain boxes going right across the ship before and a baft tho boilers? These would dispense with tho numerous holes in the deck, and their shoots, also with having to more the coal about the deck to them from where it comes in. Then instead hare a trunk or sbaft of convenient size cut in the deck fitted with a sufficiently strong batch of iron, and from this, shoots at an angle to carry the conl to nll parts of the bunkers; if ans trimming is required these shoots can be cat off by dropping a shutter in then.

Let us refer to the rarious methods now in ase at the different sards.

It seems strange that tho coaling arrangements at present are practically the saino as they were when steam was first introdnced into the Navs, nlthiough the subject lins been screral times discussed in this Institution. The ouly difference that I can sce in the last twenty-one years is that we have borrowed from abroad the sfstem of coaling with baskets, this only at the western port; and canras buckets holding about 78 lbs. are now on trial. Of course the cheapness of natire labour renders conling abroad quicker on account of the number of men that can be emplojed, and these men do little or nothing clse; bat this description of laboar makes thew, being barefooted and haring little clotling to hamper them in their morcments, adepts at it.

At the western port, alongside the docksard, the coaling is done by means of carts (carrying about a ton ench load) which bring the coal from the shed and shoot it alongside the ship; it is then passed in through the ports by means of baskets hulding about $100 \mathrm{lbs}$. each.

Bs these neaus 600 tons are taken in in 15 l hours. Here it depends upon the rapidity of the carting, the endurance and the smartncss of the manual labour.

For coaling in the Soand, hulks nre fitted with derricks and steam winches; some of these only hare one hatchway, consequently, most of the older ironclads and ressels can only coal from ono position at a time, which is a grent source of delay; this is cspecially the case with ressels having a batters, and, consequently, few ports. 'The coal 
in these halks is in bulk, and is got on board in bags, which havo to be filled by men from the ship coaling.

At l'ortloud, tho bags are first filled nt the coal wharf by men from the ship coaling, they are got into lighters fitted with no appliances, and tben hoisted on board. This is a rery tedicns process.

At Portsmonth, the coal bags are generally ready filled at the wharf, and tho lighters also are loaded with them, whence thes are hoisted in by the ship's npplinnces.

The system of loading by baskets is certainly by far the best at present; it is a question whether the smaller baskets uscd abrond aro not better, especially if ther were supplied for coaling from lighters, which is not the caso at present. At Sydnej, Cape Breton Island, ressels go alongside a wharf, down which trucks are run, and their contents, about $4 \frac{1}{2}$ tons, are shot on to the desk of the ship.

The system adrocited in this paper certainly has the following advantages over any other at present adopted, viz.: (a) Is quicker; (b) much chenper, (c) more clficient.

(a) It is quicker, because a continuous strenm of conl is alwajs pouring into the bunkers, and there is no delay hooking on bags or filling them, nor cause for desire to "stand casy" among the men, few of whom would be required, which would be a great adrantage in war-time.

(b) Cheaper, owing to saring in the cost of coal bags, which quickly wear out, and many of which are lost overboard. It would save transhipment (at present transhipment occurs twico) if colliers are used instead of the hulks as at preseut, and cosi of hulks' crerss will bo sared. If there wero two of these colliers of abont 1,000 tous each at each port, one of which could always be loading while the other was at Spithead or in the Sonnd supplying the fleet, and a wharf with tippingtrucks for the harbour, coaling would not be the lengthy operntion it is at present. 'Ihis, I submit, would be a grent saving to tho Admiralts.

I am uot quite certain abont my figures, but am not fir wrong. Welsh conl costs $7 s$. per ton at tho pit's mouth, and north countrs conl 5s. Freight to Plymouth is about 4s. 3a., and to P'ortsmouth per ton 4s. Gd.; these are low prices. The transhipment from collier to yard or lighter, roughly, 1s. 2ll. per ton; this makes the cost per ton to the shipper, taking the average, about $11 s$. $6 l$. The rate-book snys the contract price is 15 s. 2 d.; perbaps the $\Lambda$ dmiralts put something on for maintenance of hulks, cost of bags, general wear and tear, de.; but I think the ddmiralty night sare at least $5 s$. per ton by having their orru colliers fitted in the method belorr described, and have fir gienter efficiency; in time of war it would be almost imperative that they should have their own ressels, of whatever clescription used, for the reason I havo before mentioned, and because merchant captains at present are afraid to go alongside a man-of-war, and there are other reasons which will occur to all Naval Oflicers. These vessels could be classed in the same category ns the yard craft, and the saving in the expense of conl would soon pas for the building of resscls. In the case of transhipment to tho larbour depot, the new collier would 
dischargo the coal at $n$ much lower figure into the trucks, and at a much quicker zate.

(c.) It is wore cfficient because practically automatic, and not dependent on manual labour.

With regard to coaling at sea, under the same conditions of wind and weather, it would certainly have tho same advantages over the present system there as it would lave in port.

I think it hardly necessarg to discuss the way in which the conling is done on board a man-of-war. Bat suffice it to say, it is done by whips from sards, stass or derricks rigged over the ports, manual labour and steam capstan being the power emplored.

The following is a deseription of the ressel and her appliances:-

The collier can bo of any size, and fitted out as a sca-going ressel, with engines of sufticient power to insure a good speed.

The coaling apparatus is worked by steam supplied from the nain boilers; this is inportant, because no donkey or auxiliary boilers are required. 'The cxhaust steam from the coaling machinery is carried back to main condensers in engine-roum, thus kecping the water in main boilers in good condition, as no waste is required to be mado up by sen-water feed.

The conl is delivered on board the ship through telescopic iron tubes or shoots, direct, into portable funnels; or the spout on the end of shoot is placed directls into the bunker liole in the deck, and the delivers is rerulsted by the specd of conling machincrs, and may be from 20 to 200 tons per hour, as found most conrenient.

'lic holds are ceiled at sides and bottom with light plating to sccuro a smooth surface nnd facilitate the flow of coal to lower ends of booms.

'The collier is fitted with six bulkheads. The machiners for working the cnigo is fixed between the two midsbip bulkhends, and consists of one pair of swall engines to work the coal buckets, and another pait to lift and lower the hopper and conl shoots.

Hears wood rubbing pieces aro attaclicd on the sides and gunwale.

The forward part below deck is conveniently fitted up for berthing the crew. The after part below deck with calins, \&c., for Officers. The lavatories are placed under the bridge deck forward.

When in special cases of build, ballast is required, the ceiling in bottom of holds is made thicker, the space between cciling and buttom forwing a vers conveniont writer-ballast clamber.

The price is of courso dependent on the requirement and capacity, the larger tho collier the less cost per ton.

'The coaling of steamships is by this method performed very quickly, at minimum of labour and dust.

On account of the sponson ports aud overhanging gear on a manof-war's sides, the collier sliould carry rery large fenders of about sis feet in diameter; there would then be little chance of clamage being doue to either collier or warship. These fenders could casilybe made of a suitable materinl giring lightuess and clasticity, for instance, coir rope.

An exact position with regard to lying alongside is not necessarg, as 
the end of the coal shoot is quickly guyed to ang particular bunkerhole where the ccal is required. This is a rery important feature, as it gives the men timo to carefully trim the bunkers, and not interfere with tho steads delirery of coal.

The coal is delirerel into the telescopic shoot from a hopper supplied by buckets, ench of one liundredweight or other suitable capacity, attached to steel endless chains, working on barrels on the encls of a light stecl-plated boom. The upper ends of boons are linged on the barrel sbaft working in bearings secured to tho liopper. The hopper is guided vertically by the light plated steel columns, and lifted or lowered hy screws attaclied to under side of hopper, worked by suitable mechiner'y placed in the centro compartment under deck. The cleration of the bopper is decided by the position and level of coal in the holds. The two operatiors, riz., elerating coal to the hopper, and lifting or lowering the hopper with coal shoots nttached, are quito independent of euch other nad simultancous, and manipulated from the same locality; when the last part of the cargo is being delivered, the hopper is at its lowest position, with the lower ends of bucket-booms at the farthest ends of tho holds. At tho commencement of discharging cargo, the traveller-whecls on lower end of booms are resting on the surface of the conl. As the cargo is being discharged, the booms gradually radinte to the position tinted blue, the traveller wheels resting on the bottom cciling plating, then by lowering the hopper the ends of the boorns travel to the extreme linits of the holds. 'The opcrations of elerating the coal to the hopper, of lorrering or lifting the hopper with conl shoots are entirely in the hands of the enginecr, and made at intervals or continuous as may be conrenient.

When waking the rojage the apparatus is lowered to the position shown, the light steel-plated columns being telescopic, the coal shoots are turned fore and aft, the whole occupying the small central deck space shomn on plin. The whole apparatus then offers rers little surface to the wind.

When bunter-holes are inacessible to ends of coal-shools, the delisery is directed in portable tubes or trolless, and tipped at a convenient banker-hole. These trolless form part of the collier's gear, aro male light, and readils lifted on. board. The portable funnels before mentioned are also part of her gear. Thus the collier is adapted and fitted for coaling ans ship.

Mcn-of-war cau nlso use their collision mats rolled to form a fender. By these means, and with slight sray on, the hawser from the collier to the ship being made fast on the inner bow of the former, in order to allow a stream of water to pass between the two, conling at sea from a collier as described abore would not be a rery formidable operation, and in harbour would apparentls mect all requirements.

A single apparatus can be applicd casily to an orclivary collier, where the machiners can either be placed below by building a balkleend, or on deck like nn ordinny-y doukes engine. Supposing the ressel has two liolds, one can be placed at each of them, and cach apparatus can be nade to discharge 100 tons an hour. 


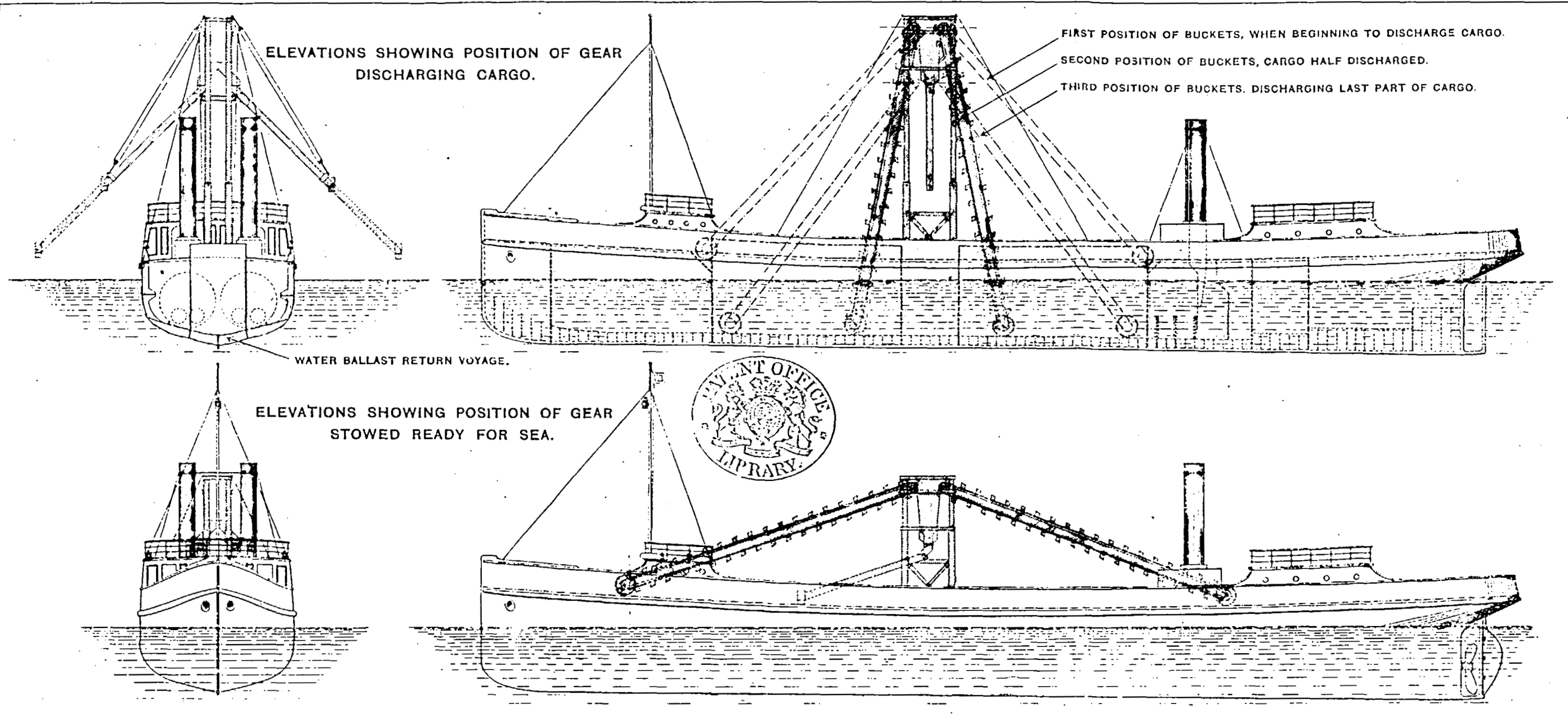

800 TON COALING FLOAT.

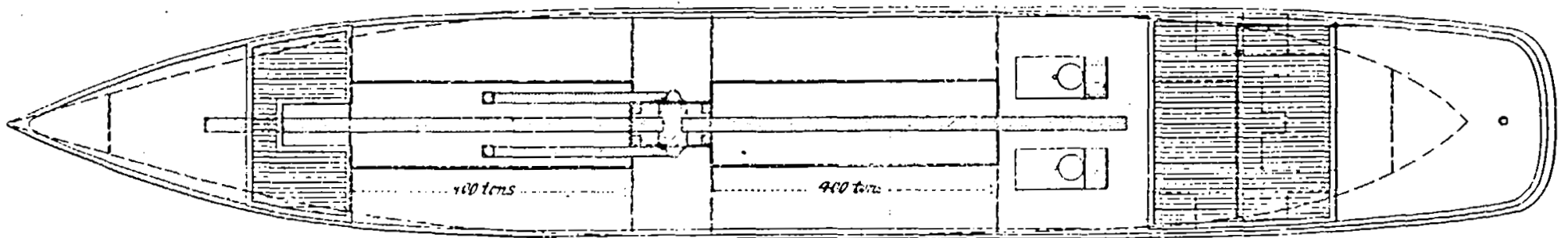

BLUE for coaling GEAR, SHOWh THUS...........

RED . . . . . . . . . ..................

PLAN SHOWING SPACE OCCUPIED ON DECK BY COALING GEAR WHEN AT SEA. 
AFr. JAYEs Rigo, C.E. : I should hare preferred that eone one clso lad beca called upon before mysclf to talic part in this discussion, and I vill cndcarour to be as brief as possiblic. JIs business is that of an engincer, and, in connection with this question of loading coal, I bare been at work now more than twents jears. In the jear 18S2 the difficulty of coaling steamers was brought before me rers promi. nently by a firm of shiporners in Lirerpool, and I ras led to take out a patent for a method of doing almust csactly what this steam collice is inteuded to accomplish. With regard to the drarings which are before $u$, I cannot help thinking that ther aro open to criticism, and that thes are hero for that purpose; and, awong other matters mhich it secws to me mas be criticized and condeusned more particularly is the buclict, which I consider would be impracticable. Huckets aro not suitable for loading cosl, and that preferred in the firs cannot be put into buclets at all, becauso it is South Wales coal, and is in far larger blocks than that obtained in Lancenshire and the North. The coal to be dealt with would require trays and nct buckets such as these. In my epecifieation I haro made a difierenco betwcen luckets, which wero a success for loading grain, and the trays, which we intended to use under sinilar circumstances to those now under discussion. I understand the booms tratcl along the cosl. If thes are not protected in their trascl from the coal I do not think it possible eatisfactorily to work the machiners which we are informed is placed amidships for raising and lowering the columns to which these booms are attached. There are other matters of detal which, I think, are open to criticism, but the object intencled to bo attained is a vers admirable one, and I think, subject to theso criticisma, this could be made perfectly practicable as a collier for coaling a man-of-war at sea. Tlere are, howerer, otlicr occasions when these, as well as ot lier ressels, hivo to be coaled, and I reuture to think thes are as important, if not more so, than coaling at sca. There are cualing station 3 of threc linds. In the first place, those in which coal is loaded from riilway trucks at a considerable elevation. Sccondly, there are station 3 such as that of the Tanjong Pagar Dock Company at Singapore, where thes take coal out in cargocs, stor it ir slieds, and that coal is subscyuently put on board the steamers by means of a large staff of coolies, the flole of the coal being carricl on these men's shoulders. Thirlly, the most important description of coaling station is such us that of the Grabd Canars Cisaling Cowpany, where the conl suust be londed out in the open, just as grain is nlso louded ut Tinganrog. These threc cases liare to be dealt with, and I think each of them is quitc as important as the one which is the cract subject under consileration. As it is of interest I will just add, with regard to this patent of ing own for a loating clerator, of which herc are the drawings, that I found, on taking it out in 1SS:, that the cost of coaling, as coupuared with wanual labour in Lirerpool, would be ns follows. The calculation from which I quote formed part of a descriptive article respeting my sjsten which appearch in "Engineering" at that time:-

"Cost of Bunlering Coal witl Patent Elerator.

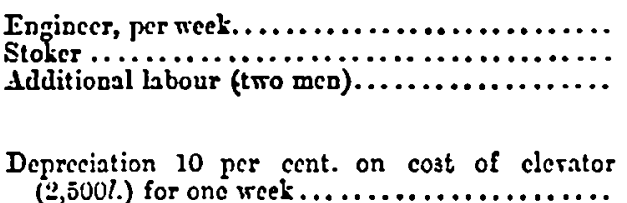

Coal and stores per weel (threc worbing days)....

Fillivg.- Eight men, cach 7 tons per Lour $=50$ tons per hour or 660 tons in 10 hours (1 day) = 1, CSO tons in 3 dass at 1 fal. per ton............

Trimming $1, \mathrm{CSO}$ tons in bunlers at $2 \frac{1}{2} d . . . \ldots \ldots$. .

Rojalty on $1,6 S 0$ tons at $0 ! d . . . \ldots \ldots \ldots \ldots \ldots$.

Present charge is 1,6s0 at 1s. Gd. .............
$\approx$ s.
200
170
2100
s. d.
5170
$\begin{array}{rrr}4 & 10 & 2 \\ 3 & 5 & 0\end{array}$
S 150
17100
3100

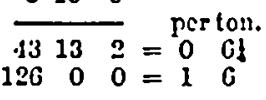

S2 $610=011$ " 
Now, the buckets nust be filled bs hand, and I renturc to asscrt, witliout fear of contradiction, that it is uttcrly impossible to load coal in the manncr shown by these buckets. It can nercr be talen up by such buclects, but must be put in by liand, and the price which is now being paid, or was then paid, was $1 f d$. a ton for that labour. The best gangs of coal steredores were found to be capable of lifting, cach man, ecren tous of coal in sirty minutes ; therefore, eight. men, being a gang capable of norking at these clerntors, cach lifting seren tuns per hour, would yesult

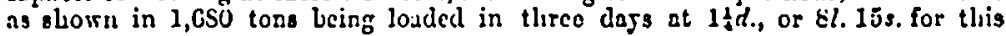
labour.

Captain FitzGrnacd: Ilow high will they lift it ?

IIr. RIGQ: Merels within a man's reach into the buckets. To this were aldecl trimming and rosalty, thus resulting in the cost shown of 6 tal per ton. The clingge then being made bj sterclores was Is. Gd.; therefore there mas an ceonomy of 113 a d. by ndopting this mechanical method of looding as distinguished from tho 55stcm of loading bJ nunual labour, if it d::L5 be called a s5stem at all; Eo that there is a los3 of 1s. per ton on tliat account. I nill not trouble jou with more detail than this, because I feel mis time ought properly to be limited, but I mas mention that I have within the last six months completed, at the request of the Presidcut of Isia Socićlé Françaisc des Houillere's du Nereri, the drawingos and sjecifications for the machiners, and it. is now being built in Irance, of au clerator which is to be crected at Venezuelat for this precise jurpose of coaling stearucrs, but steamers which can be brought alongside. There are about ten druwings licre and trenty shects of specification 3 in connection with it. The lirst drawing gires n side cleration of this portablo elerator for loadiner into side bunkers on both sides of a steamer simultancouslr.

The Cilsisys: I do not want to interrupt you, but I am a litle struck by the fact that we must not get away from the discussion of this particular pajice to another. Probably we shall bo rerg gliad to licar the details from you on at proper occasion, but your remarks are too far uray, if I mas say so.

Mr. Rica : The question of side bunlers was raisel as an incident in the paper. IIcro are side bunlers as shown in tho ecetional drawing prorided br the Freuch 'lransatlantic MIail Steamslip Company. The whole of the work is dove by one pair of winding engines and by one man, and the cxpense is found to be rery unch dess than that of mauual labour. I am perfectls eatisficd that a mechanical method of loading cosl will luswe to be adopted beforc longr. I might acld one word to what I Eaid just now. A question lias been raised as to whether the clevator described in the paper lias been tried. I understand it has not; but with regard to this one of inf own, I epent the summer of 1853 with it on the Black Sea. We loaded under test at tlic rate of about 1C0 tons per hour, and I enplojed wilh it onls a pair of 7 -inch stenm-engincs. I belicre this is tlic laresest quantity tlat has crer been turned orer within that time. The clerator with its pumtoons weighed about 70 tons.

Cuptain Firzocuscv : I do not propose to follow tho last epeaker through his explanation of his dramings: I wuald rather confue mseclf to the paper which has becu read. 1 cannot belierc, in tlie first place, that the continuous action which, if I understand it arjght, is supposct to talie place mitlı thuṣc buclicts, like an ordir:ary dredger, mould work in the way supposed. I think sometling of the lind might be derised in which jot: could fill the buclicts bs liand. 'Iliere would be very little manual labour iu shorelling the coal domn hill into the buckets and working the hoist intermittently, so to speal, clerating the coal, und getting it a gcol height, so that it will run down into the bunkers; but as to this continuous working with the closed shoots, when I hear that it has nerer been triel, I am rery nuch inclined to look at it with considenble scepticism. I think the slioots would be almust certain to clioke in a rery short tine, and those closed shoot s chobed would stop work altogether. I understaud it is not intended to be uscl for coaling nt sca. Tho last epedicer alluded to that, but I should think ang scaman who eaw that arrangenent coming alongside at sea would ask them to hazul off, and would ratler chance bugs or anj other victhod, because the whole thing is too gimerack for use at sea. There is ore point to be considered is this coaling question (of courso the Offece who read this paper is considering a man-of-war, and no: a merchant 
ship, like the list apeaker). We aro considering the conling of a man-of-mar, but ss a matter of fact the coal is put on tho deck of a man-of-war faster than it is wanted in many cast's. It is a question of stomage. Gencrully after the first hundred tons or tro are on boned thero is no uso sbooting coal on the deck. In tle inodern ships there is no deck to shoot it on to $23 \mathrm{a}$ rule. The writer says there is a grcat nelran. tage in filling up frequently before too much cosl is uscl. So there would be if you could get it in; but in the was our men-of-war are built now, in a great inany cascs sou cannot get tho coal in till about onc-third of it is out. It docs not ruil down your bunkers. You nisy burn 100 tons of coal, and jou mas say "coal ship," but sou cannot do it. From tho sliape of the bunkers tho coal won't go down; it locs not run away from the top, therefore jou cannot fill up constantly. Then there is nnother question. The writer suggests, "W'hy not make the bunkers of plain shape; wing bunkers round the engines and boilers, and plain boscs going right acros 3 the slip, before and abaft the boilcrs?" I should like to sce whit the naril arelitect hes to 825 to that. The writer eridently does not remenber that our coal is our armour in modern shiphs. 'They hare talen anas our nrinour, and we are to trust to thio coal for protection, and so far from plain bunkers running across the ship, one of the principal things wo are to trust to for armour to becp the ship frum being sunk, or tho engines being emashed, is cosl stowed in a!l zorts of in and out complicated places. Fou liare to deal with tho fact that tho bunkers are not ns you would like them to be. As wo bear that this ingenious zacline hins not been tricd, I think we are justified in saying try it before asking 119 to accept it, and I am vers much af rnid it will bo found to be utterls unpractical.

MIr. Jolls Colletr: I should like to make a few remarte on one point. The Iccturer tells us that with two collicrs for cach docksard, carrsing about 1,000 tons of coal cach, there would be a saving by his systcm of 5 s. a ton on tho present method of suppls. It is not quite cleir to my mind how that is arrirel at, but the greater part of it is apparcntly obtaincl by deducting the cost of the co:ll ut l'orts. mouth, cstimated at ils. Gd. a too, from the alleged rute-book price. So far from anj earing being effected, I am prejasred to contend that the cost woutcl be consiller. ably more than at present. Descending to details, the cost quoted of Wish coal at the pit's mouth, the freight to Portsmouth, nud of discharging, may be taken as fairls accurate, assuming, ns appears to be the case, that the data are thiose of about twelre montlis ago; but there is an crror of addition, which makes the total 12s. Gd., and not 11s. Gd. per ton. One elenent, howrerer, that of transhipment from tho collier to the yard, is usually included in the freight, and mas be talen in diminution. On the ot her hand, the cost of traosfer of cosl from the pit's mouth to the docks at Cardiff, which is, roughly spealing, about 1s. Gd. n ton, is omitted. Tho data giren, corrected in the waj I hare suggested, will make the cstimate 13s., not 11s. Gd., a ton. Again, the contract priec, alleged to be derired from the rite-bonk, is talen at 1iss. 2d. per ton; as a maiter of fast, the arerage of rate book price was 12s. 3d. last jear, the price at Portsmouth being eren under 12s. I think that these facts show that tho greater part of the alleget saving disippears at once. Certainly there would be a small saring in the number of coal bary uscl, and in wear and tear of the liulls, \&c., but it mould not amount to mucli. It is stated further that two coliicrs would bo required at cacb port, or for the four principal ports alone, eight in all. 'To compare this srstem finsncially with the present systcm, fou must cunplor the colliers continualls, so as to bring the frcight clown to whiat you fias to the increliant colliers at prescut, assuning that the Selniralty collicrs nte worked as cheapls. Wut two collicrs of 1,000 tors cicl, running continuously, tabin: the arcrigo rogage at 10 dags, viz., 1 d daj going, It das coning bick, 2 ditys loading, and 2 discharging, and a margin of 3 dass for the run, which is a moderite allowance, would considerably more than mect tho requireinents of the whole of the sards. Fou therefore hare too manj colliers for orlinary purposes, and, on the other hand, you liaro too few for quick supply. Which wanted-for in time of war or any other cnergencs what rould be the use of two, or eren cight, colliers?- - jou would want a large flect of them, not onls for supplying the home yarls, but ail the squadrons round the cosst. It would be impossible, I consider, fur tlie Admiralty, with any regard for economy, to keep always in reserve a huge flect of colliers cquipped in this manner. Supposing the mechanical plan 
adrocated wcre practicable, the only fensiblo way to giro effect to it mould be to subsidize collicrs to lecp the apparatus on board; but this would also mean a large nnnual cxpensc. In conclusion, I must confess that I do not sce, eren if the price of coal uneler both plans be taken az the snme, and I liare shown that the sctual price is less than that estimated, how jou can escape a rers much larger cost under Lieutenant Grect's plan than the present s5stem inrol-cs.

Captain Cussf l'srs, R.X.: The last speaker lias shomn that the crpense of umaintaining these colliers constantly in use would be considerable, and leeping that gear fitted mould also lead to considerablo espensc; but I do not see wis colliers should not be proridel with simple whips and derricls in the same way the colliers at Srincy are fitted, which bring the conl rousd from Licreastle and put it on board the men-of-war in the liarbour of Sydnes orcr the upper works of the higlest man-of-war at a rery nuch quicker rato than it can possibly be stowed in the bunlers. Of coiuse for the first couple of hours perliaps the run of cral is not as fast as it can be storrcd in the bunlicrs, but after that for the last two or thrco hours the delay in the stowing is so great that a rery much slower stupply of coal is all that is necled, and I think for war-tine all that would be neeled nould be that a certain number of colliers ehould be prorided with this rers simple whip and derrick apparatus, and that that mould meet all tho requirements of the citsc. These ressels ought not to be too large.

The Cmirrsax (Alwiral Colomb) : It is usual for the Cliairnan to sas a mort or tro before calling upon the lecturer to ansmer the criticisms thist hare becn offered. I think, small thounh me are in number, the discussion lias been distinctly nscful, and a great deal of light has been thrown upon the question from one or two points of riew. I understood the paper nissclf to be foundecl aluost actually upon the experience of the last jear's mancurres-I took that from what is said at the beginning of the paper-nnd that the intention was to semore those dificultics and wot to go further into the question. I lo not lnow what was in the lecturer's mind, but the question during the mancurres, as far as it canic under ing notice, mas that cither large colliers requimed some much more rapid meaus of discharme than they posscsscd, or clsc that the collicrs supplying a flect in that waj unust be small and numerous. With these large colliers there was great delay after being placed alongside one ship before thes could get to the next, and the whole Acet could not be conled till this process bad been gone through with euch ship in succession. I rather supposed, I do not know whether I aw right or not, that this arrangcment was entirels with a riew of remoring that dificultr, and I presumed the idea was that colliers emplosed by the Gorernment rould be fitted in sone methed of this lind. I am nos competent to criticize the machinery, and to say whether it would ansirer its purpose or not. We hare this ndrantage, that the centleman who is realing the paper for the lecturer is a conpetent mav, nad the firm to which he belongs is a competent frm. I think $\mathrm{M}_{\mathrm{r}}$. lligg's renurks hare becn in that was rers useful too, and that it is a great adrantage for us that cngincering firms arc turning their attention to this question, which erery nava! Officer bnows is a rery inportant une and rants to sce colred in some way. The question before us to-das, as I understand it, lias not been the sea part of the busiuess, but the cosling in harbour, nnd especially the cosling of flects in harbour under pressurc of war and array from regulas narul bases, maling attacks upon tho cnemr's coast and that sort of thing; or blockading where jou bare not your boun nppliances ready, and where those appliances must appear in the ships attached to the dect for the purpose of cosling them. I will now call upon the gentleman who read the paper to nnswer the criticisms which hare been made upon it.

3[r. IJIIIIE: With reference to the cost of csil, I took the arerage cost of Welsh cosl and north country coul at Portsmouth and Plymoutl, and I think on running it out, it cume more cractly at 11s. Gid. I could not be certain about the contrict price being 15s. 2d.; thes are Lieutenant Greet's figurez. IIr. Collett would lnom tl:e csjet present contruct price. As to the butlers, I think ebips are at the present time being built with cross buthers and wing bunkers along the cngines and boilers.

Cuptain Frtzanisad : Where?

Ir. BuIlic: In the "Camperdorn," at Portsmoutl. Tliere are also tho nater- 
ballast clinmbers, which, witlt the cahin aud ward rooms along the cnginc and boiler space, would he use for coal in war-tine.

Captilin Forzernalo: Frers bunter is diviled into nbout twonts different compartments. All I unenmt to inuly s.as thiat the wodern ships' buinkers ners unfortumatcls more conplicated than the old ones which we hisve hithesto liad to cleal witls.

Mr. I3.inLis: Of coursc we know that the stowage and trimming of cual takes the longest time, but if there nere more nen urailable for stowing the conl, which, would be tho ease if the coal werc ynt on board by maclinery, the trimuing and stowage would be done mucl quicler. With refcreuce to wachinery, I may ricntion that the size of the engines required to clerate the cosl in thic present. design would be tro 8-incli cylinders, 1f-incli stroke. The wcightits of thic differeni parts of the machincry abore decl would be: cross licad, hopper, whecls with bc:rring 3 and shafts, 3 tons $\bar{j} \mathrm{cwt}$; the tro boous mith whecls at lowet cnds and sollers, 6 tons; shoots aml nozzles, 3 tons; tro sets of 40 buclets inth chains, 4 tons 10 cirt. This makes a tolal wejghl of s35, roughly, 17 tons. The four top columns wciglt 1 to:s. Worbing out thic centre of grarity of the aborc, I found it ras about 10 feet abore dect when the whole apparstus is lowercd riady for sca. The collicr is designed to c:1rsy 800 tons of coal with a total displaccment of 1,SSO tons.

The Crarurs: : It onls remainz my pleasing duty to return rour thauks to Licutcrant Crect, in his abience, for his paner, and also to JIr. Bailic fur tio able way in which he has read it. 